\title{
ISO 9001 Implementation Barriers and Misconceptions: An Empirical Study
}

\author{
Sabah M. Al-Najjar (Corresponding author) \\ Department of Business Management, College of Administration and Economics \\ University of Baghdad, Baghdad, Iraq \\ Tel: +964-7709-726-485Ｅ-mail: sabanajar@yahoo.com
}

Maha K. Jawad

Department of Business Management, College of Administration and Economics

University of Baghdad, Baghdad, Iraq

Tel: +964-7709-726-486_E-mail: sh_mahak@yahoo.com

Received: April 14, 2011 Accepted: May 23, $2011 \quad$ doi:10.5430/ijba.v2n3p118

\begin{abstract}
Despite the widespread use of ISO 9001 and the many certified organizations in the Arab countries, only five Iraqi organizations were ISO certified at the end of 2008. The purpose of this empirical study is to examine the various barriers and misconceptions that impede ISO 9001 implementation in the service and manufacturing sectors in Iraq. In order to identify these factors a structured survey was conducted using a random sample of 50 directors in service and manufacturing organizations in Baghdad. The analysis of the survey revealed nine important factors that hinder the implementation of the standards; lack of top management commitment heads the list. In addition, ten misconceptions were identified by this study, including the top ranked belief that ISO 9001 uncovers job security. The study suggested the need to formulate a national strategy to meet the emerging ISO requirements which will enable Iraqi organizations to achieve superior quality of goods and services. This study contributes to the body of knowledge in the area of quality management systems with particular interest on Iraq. The findings of this work are limited by the sample surveyed and the geographical limits, however, the findings reached carry many implications for policy- makers in Iraq.
\end{abstract}

Keywords: ISO 9001, International Standardization Organization, Iraq, Quality Management Systems, Metastandards.

\section{Introduction}

Since its introduction in 1987, the ISO 9000 standards have received wide acceptance; the number of organizations certified for ISO 9001 has grown tremendously. According to a survey conducted by ISO in 2009 (ISO Survey, 2009) the total number of certifications at the end of 2009 exceeded one million. Table (1) presents the worldwide total of ISO 9001:2000/2008 certificates from 2000-2009, while Figure (1) shows the top 10 countries for ISO 9001 certificates as of December 2009. With respect to the Arab countries, almost all of them have certified organizations for ISO 9001; however, the Arab countries were not the early adopters of ISO 9001 as was the case with the European countries. Table (2) provides the growth of ISO certification in the Arab countries between 2004 and 2008, while Table (3) and Figure (2) present the number of ISO 9001 certifications in Arab countries by a descending order as of 2008 . It seems evident that Iraqi organizations come at the bottom of the list in the adoption of the ISO 9001 certificates. The number of ISO certificates in Iraq was 5 in 2008, this number does not, even, match the nearest countries to Iraq (Jordan, Syria, Kuwait, and Saudi Arabia) in the number of ISO certifications. Based on these facts and due to lack of research information about this field in Iraq, a strong need exists to conduct this study to comprehend and explain the implementation issues and misconceptions about ISO 9001.

The purpose of this empirical study is to investigate the reasons for this phenomenon, and to report results to policy-makers in the Iraqi organizations. We expect that the findings of this work will help the non-ISO certified organization to consider investing money and time in the adoption and the deployment of Quality Management Systems (QMS) which will, finally, lead to certification under the ISO 9001 standard. With respect to theoretical contribution, this work shall augment the knowledge in the domain of quality management within the context of developing countries 
with particular focus on Iraqi organizations. Although this type of work is not large scale, it is the first one within the area of quality management in Iraq.

\section{ISO Standards: Background}

In general there are two approaches to manage the quality of a product or a service. Product quality deals with the quality of the final product, while process quality deals with the quality of the processes required to producing goods and/or services. According to Heizer and Render (2009) quality has become so important that the world is uniting around a single quality standard which is the ISO 9000. Poksinska et al. (2002) define ISO 9000 as a family of standards which relate to QMS and are designed to assist organizations in meeting their customers' and stakeholders' needs. ISO 8402 defines the quality of a product or a service as "the totality of its features and characteristics that bear on its ability to satisfy stated or implied needs". The stated needs represent those needs that are described explicitly in the product or the service specifications. Implied needs are not explicitly declared by the customer since they exist implicitly by the product or service specifications.

West et al. (2000) indicate that The International Organization for Standardization (ISO) was created at Geneva in 1947 to provide standardization of technical specifications for products traded in the international marketplace. Levitt (2005) mentions that the acronym "ISO" is derived from the Greek word "isos" which means "equal".

According to Sousa-Poza et al. (2009) the first family of standards was issued in 1987. The standards apply to QMS in any business: for profit, not for profit, government agencies or academic institutions....etc. In fact the standards do not apply to products, but rather they apply to management systems. The ISO 1987 issue consisted of five quality standards, ISO 9000 and ISO 9004 are guidelines which pertain to the development of quality systems within the organization. ISO 9001, 9002, and 9003 are conformance standards for quality assurance systems that apply to supplier-customer relationships. These last three standards are referred to as contractual standards. The selection of each standard depends on the scope of activities of the organization. The 1987 standards were intended for quality assurance; i.e. it was more a means of verifying conformance with procedures rather than the overall process of management. According to Mead (2011) the ISO 1987 was criticized for not encouraging business improvement, and for saying little about customer services.

By 1994 a new series of ISO 9000 was issued, namely ISO 9000:1994. This issue contained five standards too (ISO 9000, 9001, 9002, 9003, and 9004), and focused on quality assurance via preventive actions rather than checking the final product. Furthermore, the standards continued to require evidence of compliance with documented procedures.

The ISO 2000 revision contained the ISO 9000 and 9004 standards, and combined the three standards: 9001, 9002, and 9003 into one standard called the ISO 9001:2000. This family of standards brought new concepts such as: quality management system instead of quality assurance, focus on customer satisfaction through the application of a quality management system based on the process approach (Figure 3), and the necessity of continuous improvement. This set of standards stressed, strongly, the role and commitment of top management in the implementation of the standards. The ISO 9001:2008 issue did not include major changes to the ISO 9001:2000. It introduced some classifications to the existing requirements of the previous issue to improve its consistency with ISO 14001:2004. No new requirements were imposed by this issue. Table (4) provides the ISO 9000:1987-2008 standards.

Levitt (2005) states that ISO 9001 requirements are based on certain quality management principles which are: Customer Focus, Leadership, Worker Involvement, Process Approach, System Approach to Management, Continuous Improvement, Factual Approach to Decision Making, and Mutually Beneficial Supplier Relationships. In general the ISO standards focus on managing core value-added processes to deliver quality. In their studies, Barnes (2000), Lankford (2000), Santos and Escanciano (2002), Magd (2005), and Herass-Saizarbitoria et al. (2010) highlighted that many adopters of QMS reported several benefits such as: increased customer satisfaction and retention, realized more efficient and effective operations, enhanced marketing, increased profits, reduced waste and increased productivity, reduced the necessity for audits, promoted international trade, and improved employee motivation and moral. The global competition and the increased awareness of customers shall continue to make quality the determinant factor of customer satisfaction, and a key success factor to achieve competitive advantage.

\section{Literature Review}

With the advent of globalization, the competitive arena and the flows of information and processes have changed radically. Many organizations have realized that to sustain competitive advantages; they must focus on the quality of the products and services they provide to customers. Erel and Ghosh (1997) addressed the problems of ISO 9000 certification in Turkey through a survey among large industrial companies. The authors reported that such studies have begun in other countries, but there has been no studies that document the status of ISO implementation in Turkey to 
uncover the profile of the companies, their motivations, and the organizational experience during and after the certification process. The study provided a view on the quality movement in Turkey, and came up with some guidelines to the international manager who is planning to do business in Turkey. Amar and Zain (2002) performed an empirical study to examine the obstacles encountered by manufacturing companies in the implementation of quality programs. The authors identified eleven pertinent factors which act as barriers to implement quality programs in Indonesia. The factors are: human resource, management, attitude towards quality, organizational culture, interdepartmental relations, raw materials, machines and equipments, information, methods, training, and finance. The authors reported that several of these eleven factors are found to hinder quality programs in other parts of the world, and therefore the remedies to these obstacles could be somewhat similar. Ho (2002) stated that organizations have found that the quality of their outputs can be used as a strategic weapon in conducting business around the world. Thus, the need for standardization of business processes has emerged as a necessity to achieve competitive edges. The QMS, offered by International Standardization Organization, provide organizations with models that help in the standardization of processes, and to facilitate the exchange of goods and services worldwide. Aslanertik and Tabak (2006) add that companies are not satisfied with becoming quality leaders through applying quality management approaches only, but they understand that sustainable growth requires leadership, human resource effectiveness, and effective business integration with suppliers.

In his study Boiral (2003) attempted to analyze the perceptions and the resistance regarding the ISO standards and the certification process. Through 50 interviews with managers from certified organization, he reported contrasting attitudes that were frequently critical of the standards. The respondents were divided into: ceremonial integrators (group A), quality enthusiasts (group B), and quality dissidents (group C). The quality dissidents manifested their discomfort with the standards and their opposition to implementing ISO standards in their organizations. The dissidents (20\% of the interviewed managers) believed that the standards: had a rather negative impact on management's practices, and had created an iron cage, the commercial advantages were uncertain, and the standards increased bureaucracy. Some dissidents believed that their organization's decision to adopt the standards was a mistake. In a study conducted on ISO certified companies in Saudi Arabia, Magd (2005) found that the three most important benefits gained from applying ISO standards were: improved efficiency of the quality system, better documentation procedures, and increased quality awareness in the organization. In addition high registration costs were viewed as a barrier to adopt ISO. The author believes that QMS could be used to achieve efficiency rather than achieving quality products in Saudi Arabia. In their study applied to companies certified for ISO 9001 in Turkey, Aslanertik and Tabak (2006) investigated the impact of customer satisfaction, cost reduction, and integration with suppliers on the financial performance of the certified companies. Their study revealed that the marketing dimension gains of ISO implementation outweigh its cost dimension. Magd and Nabulsi (2007) attempted to explore the issues associated with the implementation and certification of ISO in the Middle East in general, and in the United Arab Emirates (UAE) in specific. The study was based on the feedback obtained from 51 UAE certified organizations that represented 5\% of the total number of certified organizations. The UAE had 2422 certified organizations in 2007 (Table 2). The authors stated that the difficulties in implementing ISO 9001 came from the fact the standards define general requirements to establish quality management systems which in turn add more challenges to identify the standards' benefits and problems. They added that the internal benefits of ISO exceeded the external benefits at the certified organizations in UAE. Hesham and Magd (2007) conducted an empirical study on a sample of industrial companies in Egypt. The purpose of their study was to evaluate ISO 9001:2000 implementations in Egypt by identifying the critical success factors contributing to the success of the standards. Furthermore, the authors identified the problems associated with ISO implementation. The authors reported that management commitment was found to be an important factor contributing to the success implementation of ISO 9001, while the need to change the existing system to fit ISO 9001 and workers resistance to implement the standards were viewed as the most important problems facing the Egyptian manufacturing companies. Zeng et al. (2007) highlighted on the problems in implementing the ISO standards in China. According to the authors, the problems could be grouped into: short-sighted goal for "getting certified", over-expectation on the ISO 9001 standard, mandatory requirement (not wholehearted commitment) in some industries, and following others (the trend) in certification. With regard to the industry the authors cited the following problems: lack of commitment from some certifying bodies, excessive competition between certifying bodies, and the desire of certifying bodies to offer total package of services from consultation to certification. The authors suggested that government should intervene to improve the legal framework and to impose some schemes of control and supervisions to achieve effective implementation of ISO 9000 standards. In another study conducted in India, Bhat and Rajashekhar (2009) reported that the potential barriers to quality programs implementation are the lacks of: customer orientation, planning for quality, total involvement of top management, total involvement of workers, and resources. The authors believe that the finding of their study can help in overcoming the difficulties encountered by managers in implementing quality 
programs. Souza-Poza et al. (2009) stated that there were a number of challenges facing small and medium size organizations in their effort to implement ISO 9001 standards. The challenges were: lack of financial and human resources, inadequate technical knowledge of quality management, lack of knowledge of formalized systems, and a lack of experience in internal auditing. Cagnazzo et al. (2010) conducted an extensive review of literature to identify the impact of ISO implementation on the performance of the company. The authors, then, validated the theoretical findings through a survey on 336 Italian companies. The survey results assisted the literature findings. In this study, the authors cited the results of several authors \{Erel and Ghosh (1997), Poksinska et al. (2002), Ammar and Zain (2002), Gotzamani (2005) $\}$ concerning the barriers and pitfalls of ISO implementation. Fard and Abbasi (2010) reported that opponents of ISO 9000 claim that it is somewhat difficult to adopt ISO 9001 in the public organizations in Iran, because the standards were originated in the private-industrial sector, and thus they are not applicable to the public sector which, mainly, provides services. Lamport et al. (2010) mentioned that despite the great evidence about the benefits of ISO 9000 it is still debatable as to whether or not the standards improve business performance and profitability. The authors mentioned that most studies have examined the impact of ISO standards based on self-rated measures such as customer satisfaction, productivity and product quality. Therefore, the authors attempted to assess empirically the impact of ISO 9000 on the financial performance of a sample of companies studied in the Mauritius, Singapore. The analysis revealed that there is an association between ISO 9000 certification and the overall financial performance of the companies studied.

It could be concluded from the review of literature that regardless of the barriers, misconceptions, and opinions of proponents and opponents of ISO 9001, the ISO 9001 proved to be a good device to improve the processes of organizations through relying on a management system approach, and by focusing on the value-added activities to meet and exceed customer's expectations.

\section{The Research Problem}

The literature review provides different opinions about the benefits, the misconceptions, the pitfalls, and the barriers in adopting and implementing ISO 9001 standards. However, the majority of the research work has been conducted in the developed countries. Although the developing countries have attempted, for long time, to implement ISO 9001 to compete in domestic and international markets, we observed that the research work directed to developing countries in general, and to the Arab countries in specific is very limited. The implementation issues of ISO 9001 have been explored in many Arab countries, but almost no research work has been conducted on Iraq in this field. There is no study in the literature that documents the barriers and misconceptions about ISO 9001 implementation in Iraq. Therefore, we believe that this empirical work is worthwhile, and shall shed the light on this area. The present study is significant at this time because the opening of Iraqi markets coupled with problems facing the Iraqi business after 2003 have played an important role in sinking the Iraqi markets with foreign goods and services. Now, the Iraqi Government and the Ministry of Industry are placing great emphasis on manufacturing and service industry to achieve superior quality, through the adoption of ISO 9001, to enable local products and services to compete successfully with foreign products. Therefore, exploring the barriers and misconceptions about ISO 9001 shall facilitate the endeavors towards deploying the implementation of this standard.

\section{Research Design and Data Collection}

The present study is similar to other studies conducted in foreign and Arab countries such as Erel and Ghosh (1997), Boiral (2003), Magd and Nablusi (2007), Hesham and Magd (2007), Zeng et al. (2007), Soza-Poza (2009), and Fard \& Abbasi (2010). Although the similarity is found in the objective of determining the important factors which impede the adoption and implementation of ISO 9001. The difference between this study and the prior research work reviewed here is found in investigating the misconceptions about ISO standards which could reveal some possible indicators for factors behind the adoption of ISO 9001. No attempt is made here to test any hypothesis or to verify any relationships between variables. Our interest in this work is pure explorative.

To achieve the objective of this research, an instrument was designed to obtain evidence about the barriers and the misconceptions of adopting ISO 9001. The instrument was derived from the literature review performed in this study and was adjusted to add more clarity to the questions. The instrument used a five-point Likert scale ranged from: strongly agree (5), to strongly disagree (1). The research instrument contained thirty questions; the first fifteen questions were intended to investigate the barriers of ISO 9001 adoption, while the second fifteen questions were concerned with exploring the misconceptions about ISO 9001. The authors distributed fifty questionnaires to a random sample of directors in different organizations (27 services, and 23 manufacturing) at the city of Baghdad. The usable questionnaires were 42 so the response rate was $84 \%$. According to Saunders et al. (1997), a response rate between 30\%-50\% is appropriate. The responses were analyzed using Microsoft Excel 2003. 


\section{Research Findings and Discussion}

\subsection{Barriers to ISO 9001 Implementation}

Table (5) provides the ranking of ISO 9001 implementation barriers according to respondents' opinions. From Table

(5) it can be concluded that the most important barriers to ISO 9001 implementation are:

- Top management commitment.

- Employee resistance.

- Difficulty of performing internal audits.

- Absence of consulting boards.

- $\quad$ ISO 9001 requirements are unrealistic.

- Financial resources.

- Lack of human resources.

- Insufficient employee training.

- Insufficient knowledge about quality programs.

These findings are assisted by the studies mentioned in the previous section. As it appears, the highest quoted factor that impedes the ISO 9001 implementation is top management commitment. Lack of top management commitment as a barrier was also reported by Hesham and Magd (2007), Magd (2007), Escanciano et al. (2001), and Wiele et al. (2005). Lack of management commitment could be attributable to several factors: low education on quality, high top management turnover, and low leadership dedication to quality. The implementation of ISO 9001 can affect the whole organization, and if top management shows total dedication to quality programs, it leads to an atmosphere of continuous improvement. Top management must be convinced that the registration and certification shall enable the organization to communicate to its customers a clear commitment to quality. It should understand that a QMS shall improve the business efficiency by eliminating non value added processes. In addition, top management should demonstrate its commitment to ISO 9001 through: communicating to the organization the necessity of meeting customer and statuary requirements, defining the organization's quality policy and make it known to everyone in the organization, and insuring that quality objectives are disseminated to all levels of the organization. Some suggested actions that may be taken by top management are: participating in improvement projects, leading the organization by example, and creating an atmosphere to encourage people participation.

The second most important barrier seen by respondents was the employee resistance. Similar finding was concluded by Psomas et al. (2010). The employee resistance may come from the fear caused by a lack of information about ISO 9001 requirements, and from the belief that it will be difficult to change the mindset of employee regarding quality programs. Therefore, employee understanding and support to ISO 9001 are critical to its success. Another important barrier reported by the sample surveyed is the difficulty of performing internal audit. This factor was also found to be important by Sousa-Poza et al. (2009). Internal auditing is used as a mean of improvement and to confirm compliance with the requirements of the standards. Audits findings direct the attention of management to the areas where action is required. Lack of experience in performing internal audits is attributed to lack of understanding of the QMS, employee's level of education, lack of training, and low worker morale. It was also uncovered in this study that the absence of consulting boards is a major limitation to the effective application of ISO 9001. In fact there does not exist any foreign certifying board or any consulting agency in Iraq that can certify the Iraqi organizations for ISO 9001. The Central Organization of Standardizations and Quality Control (COSQC) is a member of the International Standardization Organization, its membership was stopped during the embargo period. Now the COSQC membership is restored, but most of its knowledgeable personnel have left this organization due to the circumstances after 2003. COSQC can provide some help in the internal auditing and quality guidelines before certification, but it has no certifying authority. Unless the COSQC's role is revived, and certifying boards start business in Iraq, the Iraqi organizations will be obliged to get assistance from certifying boards in Saudi Arabia, Jordan, Kuwait, and Syria. Off course, importing such service from outside Iraq will be more expensive than obtaining it locally.

The majority of respondents (76\%) believed that ISO 9001 requirements are unrealistic. This finding is attributable to several reasons such as: quality is realized through inspection, the standards cause sub-optimization of performance, the standards depends on people's interpretation of quality, and the standards create bureaucracy that the organization was better off without it (Seddon, 1998). Another factor that was reported by respondents is the lack of financial resources to mobilize the implementation of ISO 9001. Funds are needed to institute training programs, provide quality 
resources, payments for external consultants, payment for auditors, and payment for certification (Tamimi \& Sebastianelli, 1998), (Arora, 1996).

With respect to human resources, $73 \%$ of the respondents thought that lack of human resources was essential factor acting against the implementation of ISO 9001. A range of issues may comprise this factor such as: inadequate level of education, misinterpretation of the standards, low worker moral, and high worker turnover. The last but not the least two factors are attributed to: low level of education, lack of employee training programs, and insufficient top management commitment to quality programs.

\subsection{Misconceptions about ISO 9001}

Since ISO 9001 is not mandatory in Iraq, and due to the few ISO certified organizations, we expect that many misconception exist about the standards. Table (6) lists the misconceptions in a descending order according to respondents' opinions. The most important misconceptions are:

- ISO 9001 uncovers job security.

- ISO 9001 guarantees beating the competitors.

- $\quad$ ISO 9001 requires great financial resources.

- $\quad$ All departments must be certified for ISO 9001.

- The certificate is awarded by the ISO, Geneva.

- $\quad$ ISO 9001 certificate has no expiry date.

- ISO assures quality of goods and services.

- The certificate is awarded to private sector only.

- ISO 9001 decreases productivity.

- $\quad$ ISO 9001 certification requires a long time.

Internal auditing is the only means by which data and procedures are uncovered to external auditors before and after the certification. External auditors are bodies that are certified by the ISO and function worldwide. The internal auditors are very well trained and accredited by the ISO, Geneva. Auditors use four methods: observation, asking questions, verifying record-keeping, and selecting records. Using these methods, the auditor identifies and reports evidence about the areas where corrective actions are required. The literature does not refer to any incident where data or secrets pertaining to an organization were leaked out by internal auditors. Therefore, there is no need to worry about the data and the secrets of an organization from external auditors. With respect to the second misconception, 83\% of the respondents believe that with ISO 9001 the organization is assured of beating the competitors. ISO 9001 is a quality management system which is required by customers or countries. However, ISO 9001 does not guarantee successful competition. In fact, many non-ISO organizations are leading the competition edge such as world class companies, while many ISO certified organizations have gone bankruptcy. To succeed in the competition arena, the focus of the organization should not be on the value of the standard, but on the entire governance of this quality certification (Nayebpour \& Koehn, 2003). The third misconception delineated by respondents was the great funds required for certification. It is true that certification requires financial resources, but these resources are not inhibitive. With some employee training on internal auditing, the organization can cut the certification costs significantly. The majority of the respondents believed that all the levels in the organization must be certified. This belief comes from little education on QMS. In fact, the whole organization, or one of its departments, or one process can be qualified to obtain the ISO 9001 certification. This is one important misconception of why organizations hesitate in taking the initiative to qualify for the ISO 9001. Another major misconception about ISO 9001 is that the certificate is awarded by the ISO, Geneva. Actually, the ISO, Geneva does not certify organizations, but the registration agencies do. For instance, many registration and qualifying agencies work in Saudi Arabia and are ready to provide their services such as: BSI, DNV, SASO, 9SGS...etc, (Magd, 2005). The ISO certificate is not given for life as the majority of respondents thought. The life time of the certificate is three years only, during which several scheduled and unscheduled reviews are performed. Upon request, the organization can renew the certification or not. The ISO 9001 is not concerned with the quality of goods and services, but rather it is concerned with the quality management system within the organization. Therefore, a product marked with ISO 9001 does not imply top quality. Many respondents agreed that ISO 9001 is awarded to private organizations only. Actually, any organization (manufacturing or service) public, private, mixed, for profit, and non-profit can be ISO certified upon compliance with the requirements. In addition, the majority of the sample surveyed believed that ISO 9001 results in decreased productivity. Many companies that have implemented a 
quality management system reported cost savings through improved process, effectiveness, and efficiency. ISO 9001 can lead to improved management and operational processes, resulting in less waste in time and material, increased productivity, and cost saving (Cagnazzo et al., 2010). The last misconception about ISO 9001 is that the certification process takes long time. Depending on the size of the organization, the nature of its operations, and the maturity of its quality system, the certification process may take between 6 months to two years. ISO 9004 provides guidelines for effective action plans to implement ISO 9001 (Arora, 1996).

\section{Conclusions}

Although an extensive body of research on ISO 9001 implementation barriers exists, very little empirical research has been conducted in the Arab countries in general, and on Iraq in specific. Many organizations in the Arab countries are ISO certified with the UAE leading the trend, while Iraq comes at the bottom of the list. As a developing country, Iraq is facing a shortage of formal researches to reflect the barriers and misconceptions about QMS. To enable the Iraqi organizations in competing locally and abroad, the Iraqi government and the Ministry of Industry are encouraging Iraqi organizations to adopt ISO 9001 as a way to achieve superior quality, but so far only five Iraqi organizations are ISO 9001 certified.

This explorative study has attempted to uncover the barriers and misconceptions surrounding the implementation of ISO 9001 through a sample of 50 organizations at the city of Baghdad. The present study identified nine important barriers which impede the adoption of ISO 9001; top management commitment comes at the head of the list. The barriers identified are in line with the researches reviewed here. This study is different from prior studies because it has addressed the misconceptions about ISO 9001 and has evidenced ten misconceptions; the belief that ISO 9001 uncovers job security was top ranked.

Combining the barriers with the misconceptions leads us to conclude that ISO 9001 is not a subject of interest in the Iraqi organizations, and its implementation is still very limited. To meet the growing demand for compliance with the ISO 9001, the Iraqi government and the Ministry of Industry should formulate national strategies to comply with these emerging requirements. These strategies should include the creation of agencies to register organizations complying with ISO 9001, encourage certifying bodies to work in Iraq, lay down guidelines for training and registering auditors, educate top management and employees about ISO 9001 benefits and requirements, encourage teamwork and continuous improvement, and push towards integrated coordination within the organization. National standards boards such as COSQC, trade and industry associations, and universities have an important role in establishing viable, independent, and credible national systems that will be recognized worldwide. We stress again that top management and competent leadership are the backbone for implementing ISO 9001.

\section{References}

Amar, K., \& Zain, Z. M. (2002). Barriers to implementing TQM in Indonesian manufacturing organization. The TQM Magazine, (14)6, 367-372. doi:10.1108/09544780210447474. http://dx.doi.org/10.1108/09544780210447474

Arora, S. C. (1996). Applying ISO 9000: Quality Management Systems. International Trade Center: Geneva.

Aslanertik, E., \& Tabak B. (2006). Marketing And Cost Dimensions of ISO 9001 Implementations of Small and Medium sized Manufacturers: A Case Study Analysis. Ege Academic Review, (6)2, 47-57.

Barnes, F. (2000). Good Business Sense is the Key to Confronting ISO 9000. Review of Business, (21)1,11-16.

Bhat, S., \& Rajashekhar, J. (2009). An empirical study of barriers to TQM implementation in Indian industries. The TQM Journal, (21)3, 261-272. doi:10.1108/17542730910953031. http://dx.doi.org/10.1108/17542730910953031

Boiral, O. (2003). ISO 9000: Outside the Iron Cage. Organization Science, (14), 6, $720-737$. doi:10.1287/orsc.14.6.720.24873, http://dx.doi.org/10.1287/orsc.14.6.720.24873

Cagnazzo, L., Taticchi, P., \& Fuiano, F. (2010). Benefits, barriers and pitfalls coming from the ISO 9000 Implementation: the impact on business performances. WSEAS TRANSACTIONS on BUSINESS and ECONOMICS, (7) 4, 311-321.

Erel, E., \& Ghosh, J. B. (1997). $\quad$ ISO 9000 Implementation in Turkish Industry. International Journal of Operations and Production Management, (17)12, 1233-1246. doi: 10.1108/01443579710182972. http://dx.doi.org/10.1108/01443579710182972 
Escanciano, C., Fernandez, E. \& Vazquez, C. (2001). Influence of ISO 9000 certification on the progress of Spanish industry towards TQM. International Journal of Quality and Reliability Management,(18)5,481-494. doi:10.1108/02656710110392629. http://dx.doi.org/10.1108/02656710110392629

Fard H. D., \& Abbasi T. (2010). Questioning New Public Management: Reflection on Quality Systems in Iranian Public Sector. International Bulletin of Business Administration, (8) 72-84.

Gotzamani, K. D. (2005). The implications of the new ISO 9000:2000 standards for certified organizations - A review of anticipated benefits and implementation pitfalls. International Journal of Productivity and Performance Management, (54)8, 645-657. doi:10.1108/17410400510627507. http://dx.doi.org/10.1108/17410400510627507

Heizer, J., \& Render, B. (2009). Operations Management Flexible Version. (9 ${ }^{\text {th }}$ ed.), Prentice-Hall: Boston.

Herass-Saizarbitoria, I., Arana, G., \& San Miguel, E. (2010). An Analysis of the Main Drivers for ISO 9001 and other Isomorphic Metastandards. Review of International Comparative Management, (11)4, 562-574.

Hesham, A., \& Magd, E. (2007). ISO 9001: 2000 Certification Experiences in Egyptian Manufacturing Sector: Perceptions and Perspectives. International Journal of Quality \& Reliability Management, (25)2, 173-200. doi:10.1108/02656710810846934. http://dx.doi.org/10.1108/02656710810846934

Ho, S. (2002). Integrated management through ISO 9000:2000 and TQM. Integrated Management: Proceedings of the $6^{\text {th }}$ International Conference on ISO 9000 and TQM.

ISO, (1994). ISO 8402 Quality management and quality assurance-Vocabulary. ISO: Geneva.

ISO, (2008). The ISO survey of 2008 certifications. ISO: Geneva.

ISO, (2009). The ISO survey of 2009 certifications. ISO: Geneva.

Lamport, M., Seetanah, B., Cohhyedass, P., \& Sannassee, R. V. (2010). The association between ISO 9000 certification and financial performance. International Research Symposium in Service Management, Mauritius.

Lankford, W. M. (2000). ISO 9000: Understanding The Basics. Review of Business, (20)3.

Levett, J. M. (2005). Implementing an ISO 9001 quality management system in a multispecialty Clinic. Physician Executives, (31)6, 46-51.

Magd, H. (2005). An investigation of ISO 9000 adoption in Saudi Arabia. Managerial Auditing Journal, (21)2, $132-147$.

Magd, H. (2007). Quality Management Standards (QMS) Implementation in Egypt: ISO 9000. Global Business and Management Research: An International Journal, (2)2,57-68.

Magd, H. A., \& Nabulsi, F. (2007). ISO 9001: 2000 Implementation in UAE: An Exploratory Study. Working Paper Series-eTQM College.

Mead, B. (2011). ISO 9001 - A Brief History and Overview. Business Improvement Services.

Nayebpour, M.R. \& Koehn, D. (2003). The ethics of quality: Problems and preconditions. Journal of Business Ethics, 44(1), 37-48. doi:10.1023/A:1023282307686, http://dx.doi.org/10.1023/A:1023282307686

Poksinska, B., Kahlgaard, J.J., \& Antoni, M. (2002). The State of ISO 9000 Certification: A study of Swedish Organizations. The TQM Magazine, (14)5, 297 - 306. doi:10.1108/09544780210439734. http://dx.doi.org/10.1108/09544780210439734

Psomas, E. L., Fotopoulos, C., \& Kafetzopoulos V. D. (2010). Critical factors for effective implementation of ISO 9001 in SME service companies. Managing Service Quality, (20)5,440 - 457. doi:10.1108/09604521011073731. http://dx.doi.org/10.1108/09604521011073731

Santos, L., Escanciano, C. (2002). Benefits of the ISO 9000: 1994 system: some considerations to reinforce competitive advantage. International Journal of Quality \& Reliability Management, (19)3, 321-44. doi:10.1108/02656710210415703. http://dx.doi.org/10.1108/02656710210415703

Saunders, M., Lewis, P. \& Thornhill, A. (1997). Research Methods for Business Students, Pitman Publishing: London.

Seddon, J. (1998). The Case Against ISO 9000. ISO 9000 NEWS, 4.

Sousa-Poza, A., Altinkilinc M., \& Searcy, C. (2009). Implementing a Functional ISO 9001 Quality Management System in Small and Medium-Sized Enterprises. International Journal of Engineering, (3)3,220-228.

West, J., Cianfrani, C. A., \& Tsiakals, J. J. (2000.). Standards Outlook Quality Management Principles: Foundation of ISO 9000:2000 family. Quality Progress, 113-116. 
Wiele, T., Warden, J., Williams, R. \& Dale, B. (2005). Perceptions about the ISO 9000 (2000) quality system standard revision and its value: the Dutch experience. International Journal of Quality and Reliability Management,(22)2,101-119. doi:10.1108/02656710510577189. http://dx.doi.org/10.1108/02656710510577189

Zeng, S. X., Tian, P., \& Tam, C. M. (2007). Overcoming Barriers to Sustainable Implementation of the ISO 9001 System. Managerial Auditing Journal, (22)3, 244-254. doi:10.1108/02686900710733125. http://dx.doi.org/10.1108/02686900710733125

Table 1. Worldwide Total of ISO 9001:2000-2009 Certificates.

\begin{tabular}{|c|c|c|c|}
\hline Year & No. of Certificate & Year & No. of Certificate \\
\hline 2000 & 457834 & 2005 & 773867 \\
\hline 2001 & 510349 & 2006 & 896929 \\
\hline 2002 & 561767 & 2007 & 951486 \\
\hline 2003 & 497919 & 2008 & 982832 \\
\hline 2004 & 660132 & 2009 & 1064785 \\
\hline
\end{tabular}

Source: ISO Survey, 2009

Table 2. Growth of ISO 9001 Certification in Arab Countries between 2004 and 2008

Source: ISO Survey, 2008.

\begin{tabular}{|c|c|c|c|c|c|}
\cline { 2 - 6 } \multicolumn{1}{c|}{} & \multicolumn{5}{c|}{ Year } \\
\hline Country & 2004 & 2005 & 2006 & 2007 & 2008 \\
\hline Algeria & 126 & 183 & 103 & 171 & 159 \\
\hline Bahrain & 99 & 107 & 116 & 126 & 220 \\
\hline Egypt & 810 & 1326 & 1928 & 1535 & 1944 \\
\hline Iraq & 0 & 0 & 3 & 5 & 5 \\
\hline Jordan & 278 & 293 & 248 & 283 & 343 \\
\hline Kuwait & 101 & 111 & 141 & 184 & 254 \\
\hline Lebanon & 154 & 167 & 193 & 296 & 221 \\
\hline Libya & 6 & 35 & 46 & 55 & 26 \\
\hline Morocco & 296 & 403 & 457 & 504 & 405 \\
\hline Oman & 250 & 267 & 311 & 349 & 405 \\
\hline Palestine & 29 & 27 & 34 & 25 & 57 \\
\hline Qatar & 94 & 97 & 101 & 177 & 182 \\
\hline Saudi Arabia & 394 & 642 & 710 & 645 & 876 \\
\hline Sudan & 37 & 32 & 55 & 82 & 77 \\
\hline Syrian Arab Republic & 240 & 248 & 272 & 297 & 333 \\
\hline Tunisia & 123 & 380 & 585 & 690 & 848 \\
\hline United Arab Emirates & 819 & 963 & 1040 & 2422 & 3283 \\
\hline Yemen & 9 & 12 & 16 & 14 & 8 \\
\hline
\end{tabular}

Table 3. Number of ISO 9001 Certifications in Arab Countries by a Descending Order as of 2008

\begin{tabular}{|c|l|c|}
\hline \multicolumn{1}{|c|}{ Country } & $\begin{array}{c}\text { No. of } \\
\text { Certificates }\end{array}$ \\
\hline 1 & United Arab Emirates & 3283 \\
\hline 2 & Egypt & 1944 \\
\hline 3 & Saudi Arabia & 876 \\
\hline 4 & Tunisia & 848 \\
\hline 5 & Oman & 405 \\
\hline 6 & Morocco & 405 \\
\hline 7 & Jordan & 343 \\
\hline 8 & Syrian Arab Republic & 333 \\
\hline 9 & Kuwait & 254 \\
\hline 10 & Lebanon & 221 \\
\hline
\end{tabular}




\begin{tabular}{|c|l|c|}
\hline 11 & Bahrain & 220 \\
\hline 12 & Qatar & 182 \\
\hline 13 & Algeria & 159 \\
\hline 14 & Sudan & 77 \\
\hline 15 & Palestine & 57 \\
\hline 16 & Libya & 26 \\
\hline 17 & Yemen & 8 \\
\hline 18 & Iraq & 5 \\
\hline
\end{tabular}

Source: ISO Survey, 2008

Table 4. ISO 9000:1987-2008 Standards

\begin{tabular}{|c|c|}
\hline \multicolumn{2}{|r|}{ ISO 1987} \\
\hline ISO 9000 & Quality management and assurance standards for selection and use. \\
\hline ISO 9001 & $\begin{array}{l}\text { Quality systems model for quality assurance in organizations whose processes } \\
\text { include design, development, production, installation and servicing. }\end{array}$ \\
\hline ISO 9002 & $\begin{array}{l}\text { Quality systems model for quality assurance in organizations whose processes } \\
\text { include production and installation, but not design and development. }\end{array}$ \\
\hline ISO 9003 & $\begin{array}{l}\text { Quality systems model for quality assurance in organizations whose processes } \\
\text { use final inspection and testing to meet product and service quality requirements. }\end{array}$ \\
\hline ISO 9004 & Quality management and quality system element guidelines. \\
\hline ISO 8402 & Vocabulary and Terminology \\
\hline \multicolumn{2}{|r|}{ ISO 1994} \\
\hline & ISO 9000, 9001, 9002, 9003, 9004, and 8402 \\
\hline \multicolumn{2}{|r|}{ The focus is on quality assurance through preventive actions. } \\
\hline \multicolumn{2}{|r|}{ ISO 2000} \\
\hline ISO 9000 & $\begin{array}{l}\text { Quality management system fundamentals and vocabulary- defines terminology } \\
\text { and standards. }\end{array}$ \\
\hline ISO 9001 & $\begin{array}{l}\text { Quality management systems requirements- } \quad \text { used to assess compliance with } \\
\text { requirements (combines ISO 9001/9002/9003 into one standard) }\end{array}$ \\
\hline ISO 9004 & $\begin{array}{l}\text { Quality management systems guidelines for performance improvement- offers } \\
\text { guidance for continual management system improvement. }\end{array}$ \\
\hline \multicolumn{2}{|r|}{ ISO 2008} \\
\hline $\begin{array}{l}\text { Introduced som } \\
\text { consistency witl }\end{array}$ & $\begin{array}{l}\text { fications to the existing requirements of the previous issue to improve its } \\
\text { 14001:2004 }\end{array}$ \\
\hline
\end{tabular}


Table 5. Ranking of ISO 9001 Barriers According To Respondents' Views

\begin{tabular}{|c|c|c|c|c|c|}
\hline Rank & Barriers & $\begin{array}{l}\text { Respo- } \\
\text { dents* }\end{array}$ & Mean & STDV & $\mathrm{COV}$ \\
\hline 1 & $\begin{array}{l}\text { Top management } \\
\text { commitment }\end{array}$ & 38 & 4.38 & 0.82 & 0.187 \\
\hline 2 & Employee resistance & 36 & 4.21 & 0.98 & 0.233 \\
\hline 3 & $\begin{array}{l}\text { Difficulty of performing } \\
\text { internal audits }\end{array}$ & 35 & 4.16 & 1.09 & 0.262 \\
\hline 4 & $\begin{array}{l}\text { Absence of consulting } \\
\text { boards }\end{array}$ & 34 & 4.07 & 1.15 & 0.283 \\
\hline 5 & $\begin{array}{l}\text { ISO } 9001 \text { requirements } \\
\text { are unrealistic }\end{array}$ & 32 & 3.97 & 1.25 & 0.315 \\
\hline 6 & $\begin{array}{l}\text { Shortage of financial } \\
\text { resources }\end{array}$ & 32 & 3.92 & 1.06 & 0.270 \\
\hline 7 & $\begin{array}{l}\text { Insufficient human } \\
\text { resources }\end{array}$ & 31 & 3.90 & 1.31 & 0.336 \\
\hline 8 & $\begin{array}{l}\text { Insufficient employee } \\
\text { training }\end{array}$ & 29 & 3.78 & 1.36 & 0.360 \\
\hline 9 & $\begin{array}{l}\text { Insufficient knowledge in } \\
\text { quality programs }\end{array}$ & 24 & 3.59 & 1.33 & 0.370 \\
\hline 10 & $\begin{array}{l}\text { Ignorance of ISO } \\
\text { importance }\end{array}$ & 18 & 2.97 & 1.54 & 0.519 \\
\hline 11 & $\begin{array}{l}\text { Weak interdepartmental } \\
\text { relations }\end{array}$ & 14 & 2.76 & 1.48 & 0.536 \\
\hline 12 & $\begin{array}{l}\text { Unwillingness to change } \\
\text { work systems }\end{array}$ & 12 & 2.69 & 1.49 & 0.554 \\
\hline 13 & $\begin{array}{l}\text { Inflating the size of } \\
\text { documents }\end{array}$ & 10 & 2.57 & 1.34 & 0.521 \\
\hline 14 & $\begin{array}{l}\text { Unwillingness to change } \\
\text { organizational culture }\end{array}$ & 8 & 2.26 & 1.25 & 0.553 \\
\hline 15 & $\begin{array}{l}\text { Absence of quality } \\
\text { guidelines }\end{array}$ & 8 & 2.23 & 1.37 & 0.614 \\
\hline
\end{tabular}

*Total of strongly agree + Agree 
Table 6. Ranking of Misconceptions about ISO 9001 According to Respondents' Views

\begin{tabular}{|c|c|c|c|c|c|}
\hline Rank & Misconceptions & $\begin{array}{l}\text { Respo- } \\
\text { dents* }\end{array}$ & Mean & STDV & $\mathrm{COV}$ \\
\hline 1 & $\begin{array}{l}\text { ISO } 9001 \text { uncovers job } \\
\text { security }\end{array}$ & 39 & 4.38 & 0.64 & 0.15 \\
\hline 2 & $\begin{array}{l}\text { ISO } 9001 \text { guarantees } \\
\text { beating the competitors }\end{array}$ & 35 & 3.57 & 1.53 & 0.43 \\
\hline 3 & $\begin{array}{l}\text { ISO } 9001 \text { requires great } \\
\text { financial resources }\end{array}$ & 35 & 4.23 & 0.94 & 0.22 \\
\hline 4 & $\begin{array}{l}\text { All departments must } \\
\text { be certified for ISO } \\
9001\end{array}$ & 35 & 4.11 & 1.05 & 0.26 \\
\hline 5 & $\begin{array}{l}\text { The certificate is } \\
\text { awarded by the ISO }\end{array}$ & 33 & 3.97 & 1.22 & 0.31 \\
\hline 6 & $\begin{array}{l}\text { ISO } 9001 \text { certificate has } \\
\text { no expiry date }\end{array}$ & 32 & 4.00 & 1.17 & 0.29 \\
\hline 7 & $\begin{array}{l}\text { ISO assures quality of } \\
\text { goods and services }\end{array}$ & 31 & 3.95 & 1.31 & 0.33 \\
\hline 8 & $\begin{array}{l}\text { The certificate is } \\
\text { awarded to private } \\
\text { sector only }\end{array}$ & 28 & 3.85 & 1.30 & 0.34 \\
\hline 9 & $\begin{array}{l}\text { ISO } 9001 \text { decreases } \\
\text { productivity }\end{array}$ & 26 & 3.67 & 1.49 & 0.41 \\
\hline 10 & $\begin{array}{l}\text { ISO } 9001 \text { certification } \\
\text { requires a long time }\end{array}$ & 22 & 3.33 & 1.50 & 0.45 \\
\hline 11 & $\begin{array}{l}\text { ISO } 9001 \text { success is } \\
\text { employee responsibility } \\
\text { only }\end{array}$ & 20 & 2.95 & 1.63 & 0.55 \\
\hline 12 & $\begin{array}{l}\text { ISO } 9001 \text { inflates the } \\
\text { organizational structure }\end{array}$ & 20 & 3.11 & 1.54 & 0.50 \\
\hline 13 & $\begin{array}{l}\text { ISO } 9001 \text { creates } \\
\text { functional conflicts }\end{array}$ & 17 & 2.58 & 1.31 & 0.53 \\
\hline 14 & $\begin{array}{l}\text { ISO } 9001 \text { certificate is } \\
\text { a managerial luxury }\end{array}$ & 10 & 2.54 & 1.47 & 0.58 \\
\hline 15 & $\begin{array}{l}\text { ISO } 9001 \text { does not } \\
\text { match the Iraqi culture }\end{array}$ & 9 & 2.47 & 1.39 & 0.56 \\
\hline
\end{tabular}

*Total of strongly agree + Agree 


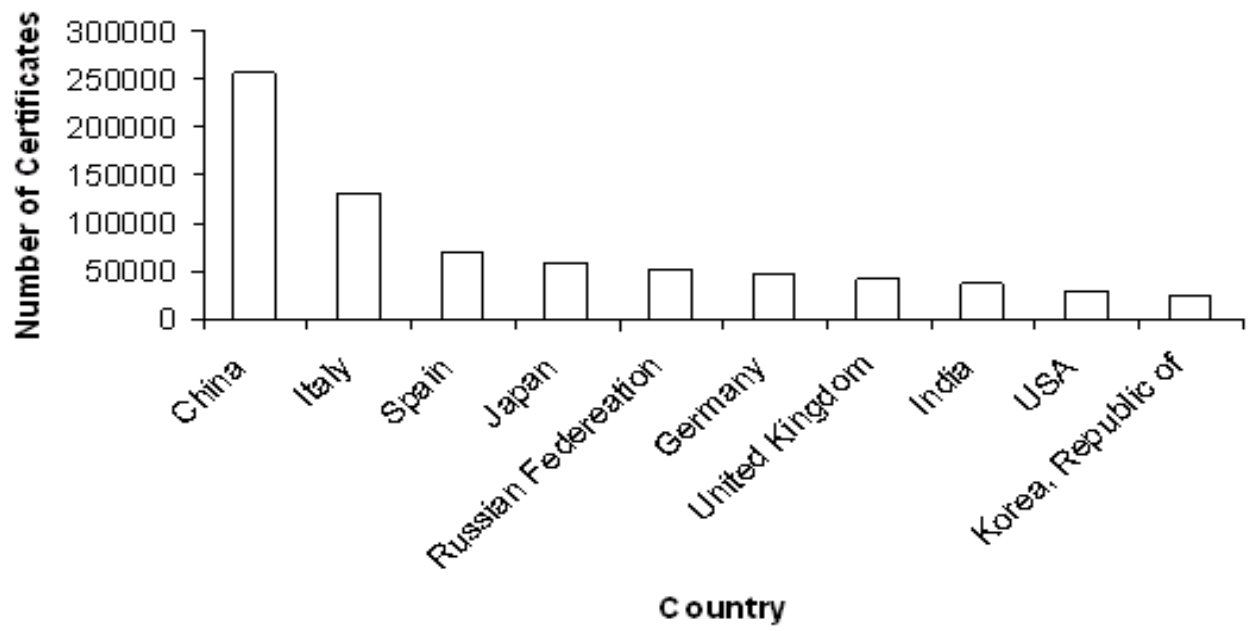

Figure 1. Top Ten Countries for ISO Certification in 2009

Source: ISO Survey, 2009.

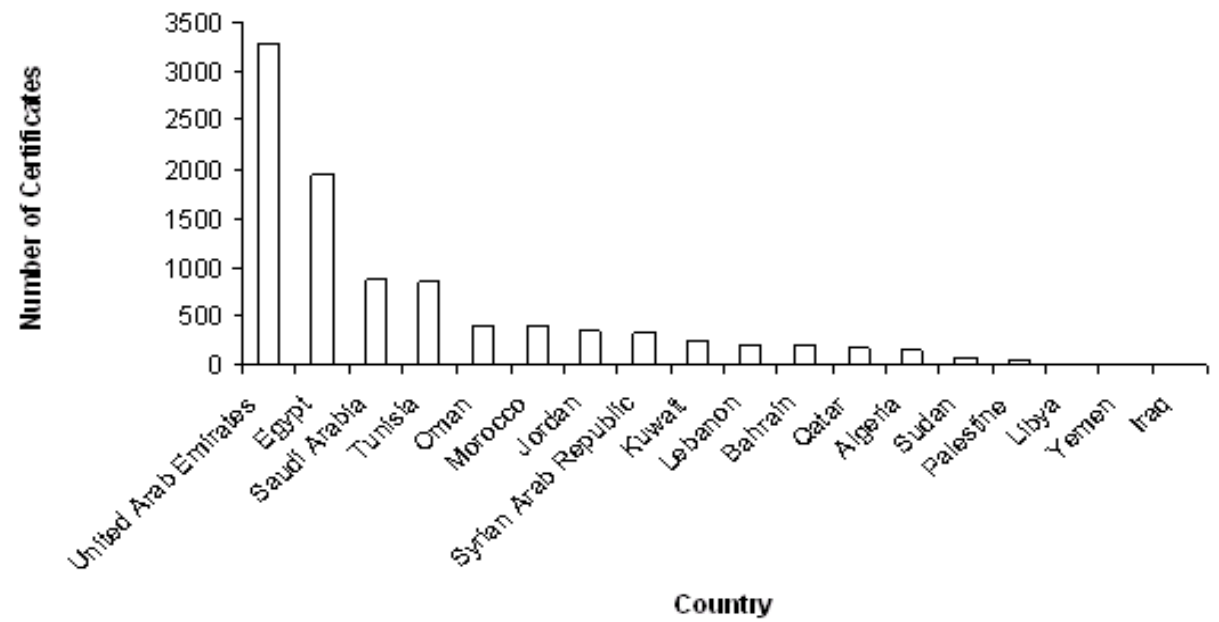

Figure 2. Graphic Representation of ISO 9001 Certifications in the Arab Countries as of 2008 Source: ISO Survey, 2008. 


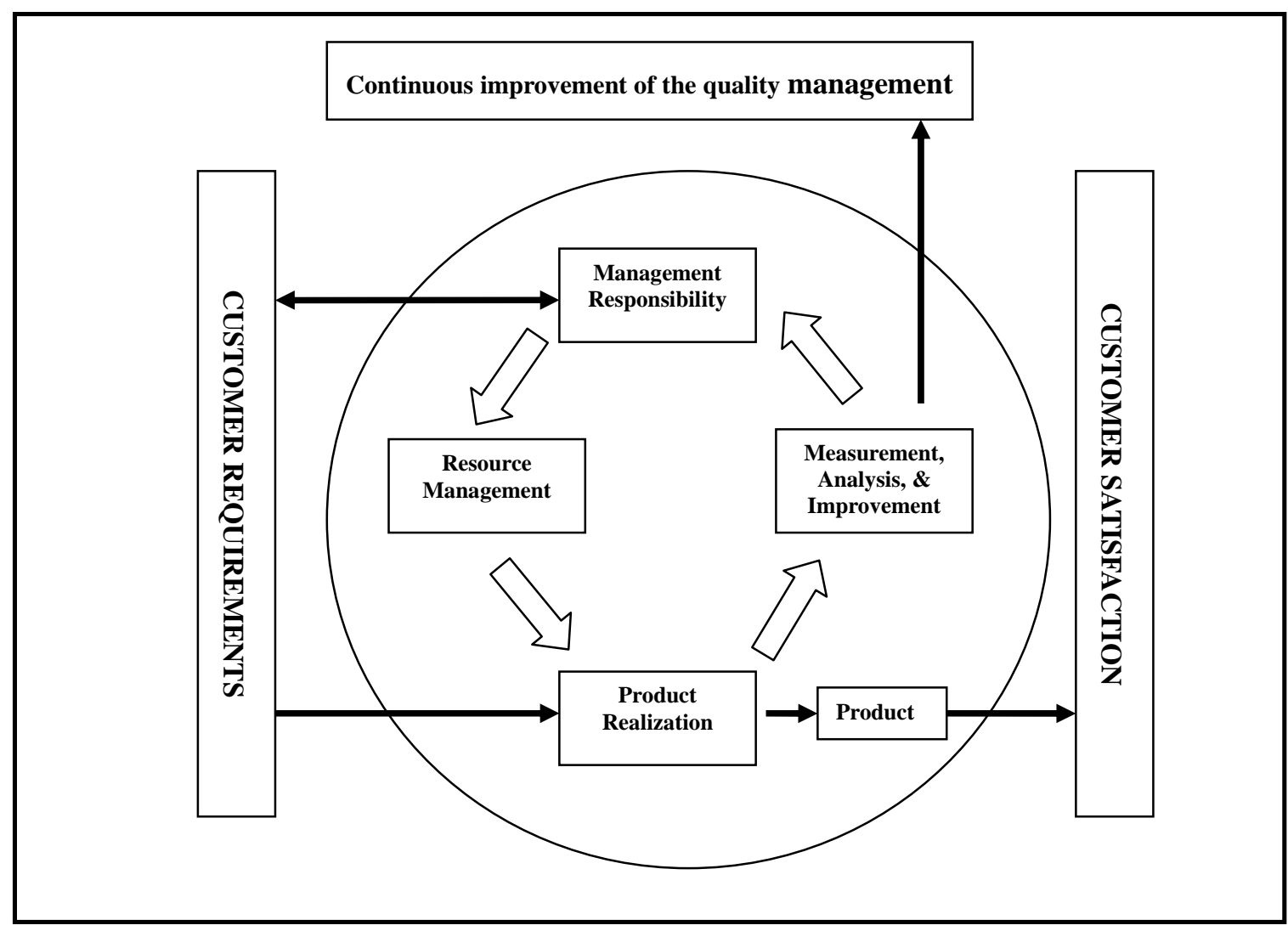

Figure 3. ISO 9001:2000 Process-Based Quality Management System 